\title{
Brand Adoption by BoP Retailers
}

\section{Prof. Piyush Kumar Sinha, IIMA, India; Prof. Suraksha Gupta, Brunel Business School, Brunel University, UK and Saurabh Rawal, IIMA, India}

\begin{abstract}
Previous studies with regard to brand adoption by retailers have focussed on large retailers who are approached directly by the brands. There is a lack of studies on how BoP retailers adopt brands who sell to a very different set of customers and are served indirectly through long indirect channels. Most studies have approached the subject from a distribution perspective of reaching to these markets. Sixty retailers belonging to different villages of Central and North Gujarat, were interviewed to understand their brand adoption process. The interviews were audio recorded, transcribed and analysed. A grounded theory based analysis was carried out. The analysis brought out six criteria used by the retailers in selecting brands with demand for the brand as the most dominant factor. Other criteria included brand adoption by other retailers, profitability, influence of wholesaler/distributor, and packaging.
\end{abstract}

Keywords: Bottom of the pyramid, retailers, brand adoption, distribution 


\section{Introduction}

The Bottom of the Pyramid (BoP), also referred to as the Base of the Pyramid, or the next billion customers, has caught the attention of many consumer packaged goods (CPG) companies, especially in the last decade. Prahlad and Hammond (2002) and Prahlad and Hart (2002) positioned the BoP population as a consuming class which is poor yet offers opportunities for high growth and profits to businesses. These consumers predominantly live in smaller towns and rural areas.

The BoP population was initially defined as people who live on less than \$1 a day (World Bank reference). Another definition given the World Resource Institute (WRI) and the As per the estimates of the International Finance Corporation (IFC), base of the pyramid is defined using a cut off of USD 1.72 per person per day in the Indian context. However, this definition is not adequate to define the BoP as it considers only the income of an individual while neglecting other important aspects of poverty. A recent report by World Bank titled 'Voices of the Poor', states that the BoP description is multi-dimensional so it cannot be solely based on income levels and therefore it will consider factors such as lack of access to basic goods, services and economic opportunities. Thus the IFC elaborated the definition by including two more non-monetary aspects, namely, lack of basic goods and services and lack of income generation opportunities.

The business potential that exists in these segments is starting to interest businesses offering branded products because urban markets have become highly competitive for their brands (Burgess and Steenkamp, 2006). However, lack of knowledge about brand value sought after by consumers and channel that caters to consumers in this segment dissuades suppliers of branded products to consider entering these markets. Supplier brands currently serving BoP consumers hesitate to directly approach retailers operating in rural markets and prefer to use alternative routes to address demand in this segment. Distributor companies as member of the business-to-business network of supplier's brand facilitate availability of its products to consumers through local retailers operating in rural areas (Reinartz et al., 2011).

India has about 13 million stores, out of which 6 million stores deal in CPG. The share of modern and large stores is less than $10 \%$. Some of the leading companies reach to about 5.5 
million of these stores. Only about $20 \%$ of these stores are service directly by the company through their field force. The rest $80 \%$ are covered indirectly through a long chain of distribution primarily controlled by wholesalers.

In many cases, customers face stock outs or higher prices. It is also found that the cost of serving these markets, especially in the rural India, is higher and in many cases manufacturers had to withdraw new product introductions. Therefore, manufacturers have found it a challenge to not only reach these outlets but also ensure the desired brand experience. The role of the village level retailer becomes important. This paper stresses on the importance of the role a retailer and attempts to examine how retailers serving the bottom of the pyramid markets adopt brands.

\section{Adoption by Retailers}

Previous studies have been conducted to find out the factors that retailers consider while adopting new brands. However, given the importance of this phenomenon they are limited. The first study was published in Grahshof (1970) which addressed two primary decisions affecting the mix of products carried by a retail chain. These were related to (a) the addition of new items, and (2) the deletion of items now stocked by the chain. The main factors considered by a retailer for addition were demonstrated consumer demand, promotional programme of the suppliers, rate of movement, competitive reaction to the new item, test market information and the estimated sales as presented by the supplier. The most important criterion in the evaluation of an item being considered for deletion is its rate of sales, gross margin percentage of the item, the gross margin dollars earned, the item's role in the mix of items carried by the chain and return on inventory investment. Heeler, Kearney and Mehaffey (1973) found a similar list of 13 items that affected the choice of a product by supermarket chains. They also found that these could be used in an additive or compensatory model. Montegomery (1975) added variables to the study related to category performance and shelf space utilisation.

There was long gap before studies started focussing on this phenomenon. In a study to understand the decision of a channel intermediary to add new products Rao and Mcluaghlin (1989) used a group of four variables of financial, competition, marketing strategy of vendors and category variables. Later White, Troy and Gerich(2000), Rao and Mahi (2003) 
and Lariviere and Padmanabhan (1997) studied the role of slotting fees and introductory allowances in the acceptance of new products. They found that these could be used to offset the perceived risk of a new product. However, this effect was more pronounced in an interaction based model, indicating that these would become more effective in the presence of other variables such as manufacturer reputation, retail competition, and category sales volume. It is also noted that these variables are beyond the control of the manufacturers and hence difficult to manage. Hence retailers may not bring slotting fees and introductory allowances in choosing a product, but use it for increasing their revenues. Ailwadi (2001) found that trade promotions, consumer promotions and private brands were used by retailers and manufacturers to manage the balance of power between, though the effects might not always be in the desired direction. Retailers tend to adopt private labels to counter the manufacturers and increase profitability (Kumar and Steenkamp, 2007).

A shift in focus has been noted in the recent study in this regard. Researchers have started focussing on the relational aspect of the decision. Corsten, Daniel and Nirmalya Kumar (2005) explored the influence of collaborative efforts in adoption of Efficient Consumer response (ECR) by large retailers. They found that transaction-specific investments, crossfunctional teams and incentive systems had a positive impact on adoption. The adoption had a positive effect on the supplier's perceptual economic performance, archival sales and capability development. Retailer capabilities have a positive effect on supplier perceptual economic performance, archival service performance and capability development. In a study of buyers' selection of new products in grocery stores, Kaufman, Jaychandran and Rose (2006) demonstrate the role of firm-firm and buyer-salesperson relationships in retailers' acceptance of new products. The findings indicated the increasing influence of buyersalesperson and firm-firm relationships when a new product's attractiveness is modest than when the new product is very unattractive or very attractive. In such a situation, the likelihood of new product acceptance could increase substantially based on a strong relationship of the buyer with the salesperson. A similar finding is reported in firm - firm relationship. Using trust, commitment and satisfaction, they infer that when the product is judged to be unambiguously weak or strong, buyers feel that the perceived risk could be reduced through relationship quality. Jap and Anderson (2007) studied the role of relationship length in adopting a new product. They indicated that goal congruence and 
information exchange norms change over the relationship lifecycle and the willingness to adopt new products may change with the length of the relationship. More recent literature (Dholakia et. al., 2012) emphasizes on the role of caste and family relationship within retail establishments and between wholesale and retail establishments hinting at the deep ethnosocial fabric which plays an important role in business decision pertaining to procurement and credit policies. The study also makes a separate mention about the existence of ethnicgroups in the wholesale and retail trading communities in India, thus, signifying the possibility of the influence of caste in the procurement of goods.

In an ethnographic study of retailers, Varman and Costa (2009), illustrate that the ties among the retailing community are deep seated in the socio-economic framework which is an important tool that helps them grow and survive. Moreover, they also discovered that most permanent shops were simply an extension of the homes of the shopkeeper. Therefore, such literature accentuates the need to further explore and understand not only the role of retailers and trade partners but also that of the family in business decisions.

In a recent study, Everdingen et al (2011) used a combination of profit, category and relationship variables to understand product adoption by a chain of stores in Europe. They found that in each case, the relation with adoption in non-linear. A positive linear effect of the perceived new product uniqueness on a retailer's utility to adopt has been found indicating that higher levels of uniqueness was associated with higher levels of retailer adoption probability. They also find that the relationship quality is not very significant. The expected category growth due to the new product introduction is positively associated with new product adoption as well as adoption by competing retailers. The probability of adopting a new product appears to be higher when a larger number of competing retailers has already adopted the new product. They also find that the adoption levels differ systematically between buyers and retail chains.

\section{Methodology}

Most studies in this area have used some of other type of models including simulation. They have used data from manufacturers as well as retailers. Most of these studies focus on the 
adoption by large retailers. The studies related to small retailers are limited and those relating to BoP retailers are scanty. Sixty retailers serving this population were selected. The cities in India possess mixed habitation. The customers belonging to different socioeconomic strata live in the same locality. They also tend to buy from the same retailers. This is much more pronounced in food and grocery where Kiranas dominate. The share of new format self-service stores is still very low. The stores, therefore, were selected carefully so that these largely served the BoP customers.

\section{Method}

The purpose of the study was to develop a theory about the brand adoption behaviour of retailers serving the bottom of the pyramid market. Moreover, in order to ensure all possible existing themes were captured, the study was specifically designed to be openended. A discussion guide was prepared that contained broad questions about how BoP retailers adopted brands.

Villages in 4 districts of the Indian state of Gujarat were selected to represent the BoP customers. In-depth interviews were conducted with 60 retailers from 28 villages belonging to these districts. These retailers were a suitable group because they served a population, which did not have high-income sources. Majority of the people in the villages worked in the agriculture sector and some others worked as daily labourers in nearby Talukas ${ }^{1}$. Moreover, the population of these villages had no or limited access to basic facilities likes healthcare, education and sanitation. Therefore, as per the definition of BoP by IFC, most of the findings reflected the existence of BoP population in these villages. The survey was conducted in villages where the population ranged from 834 to 30871 . The population of only 3 villages were in excess of 5000. A total of 7 retailers were covered from these 3 villages but these retailers were located in the peripheral areas and away from main the village, where these retailers sold goods only to BoP consumers, primarily contractual labourers at construction sites. Some of the villages had primary schools. The population of some of the villages had access to a clinic in the village, while others were required to visit the nearest Taluka for medical help. All the 60 shopkeepers who were interviewed were males. The average size of

\footnotetext{
${ }^{1}$ The nearest town that works as a feeder market to the surrounding areas (blocks and villages) with an approximate radius of $25 \mathrm{kms}$.
} 
the store was approximately 100 square feet with the smallest store measuring about 30 square feet and the largest measuring about 250 square feet in size. Each village had multiple shops which were generally located in different parts of the village and served a faintly distinct area. The villages did not have defined areas like markets, roads, and parks. In most of the cases the shops were located with the villagers' residences.

The retailers sold a wide range of products, FMCG, cereals, vegetables, footwear, stationery, tobacco products, electronic items and mobile recharge coupons. Majority of the income of these retailers came from processed and raw food items. Some of them also sold electronic goods like batteries and torches and flashlights.

All the interviews were conducted in person and at the retailer's shop mostly in the afternoon when they were to participate in the discussion. The retailers were interviewed only if they gave their consent to be a part of the study and those who were reluctant were not interviewed. The retailers were informed that the objective of the study was to understand how retailers decide which brands to select or reject and the reasoning behind such a decision. No systematic differences in the quality of data or in the substance of interviews conducted in different ways was detected. Wherever required they were asked to cite examples and cases to bring out the dimensions. The average length of interviews was 24 minutes, the longest one lasting for 88 minutes. The interviews were audio-recorded and they yielded about 400 pages of transcript.

\begin{tabular}{|c|c|c|c|c|}
\hline $\begin{array}{c}\text { Number of } \\
\text { samples }\end{array}$ & Village & Taluka & District & Population $^{2}$ \\
\hline $\mathbf{2}$ & Shrinagar & Sanand & Ahmedabad & $600-650^{*}$ \\
\hline $\mathbf{1}$ & Kodaliya & Sanand & Ahmedabad & 834 \\
\hline $\mathbf{2}$ & Gokulpura & Sanand & Ahmedabad & $1000-1500^{*}$ \\
\hline $\mathbf{1}$ & Khicha & Sanand & Ahmedabad & 1883 \\
\hline $\mathbf{3}$ & Lekhamba & Sanand & Ahmedabad & 1356 \\
\hline $\mathbf{1}$ & Fangdi & Sanand & Ahmedabad & 2430 \\
\hline $\mathbf{1}$ & Goraj & Sanand & Ahmedabad & 4242 \\
\hline $\mathbf{3}$ & Bareja & Daskroi & Ahmedabad & 15427 \\
\hline $\mathbf{1}$ & Bavla & Daskroi & Ahmedabad & 30871 \\
\hline $\mathbf{2}$ & Khodiyar & Daskroi & Ahmedabad & 2915 \\
\hline
\end{tabular}

\footnotetext{
2 Data taken from Census 2011, Government of India (Ministry of Home Affairs) http://censusindia.gov.in/PopulationFinder/Population_Finder.aspx [Accessed on 13th March, 2014]

* Population of these villages was taken as mentioned by the retailers
} 


\begin{tabular}{|c|c|c|c|c|}
\hline $\mathbf{3}$ & Shilaj & Daskroi & Ahmedabad & 4341 \\
\hline $\mathbf{1}$ & Bhadaj & Daskroi & Ahmedabad & 2281 \\
\hline $\mathbf{1}$ & Lilapur & Daskroi & Ahmedabad & 1231 \\
\hline $\mathbf{3}$ & Rajoda & Bavla & Ahmedabad & 3392 \\
\hline $\mathbf{1}$ & Rasam & Bavla & Ahmedabad & 2761 \\
\hline $\mathbf{3}$ & Dhanaj & Kalol & Gandhinagar & 2259 \\
\hline $\mathbf{1}$ & Palsana & Kalol & Gandhinagar & 3691 \\
\hline $\mathbf{2}$ & Jaspur & Kalol & Gandhinagar & 2934 \\
\hline $\mathbf{2}$ & Rancharda & Kalol & Gandhinagar & 2770 \\
\hline $\mathbf{2}$ & Jank & Gandhinagar & Gandhinagar & $1000-1500^{*}$ \\
\hline $\mathbf{1}$ & Panchha & Danta & Banaskantha & 1306 \\
\hline $\mathbf{3}$ & Danta & Danta & Banaskantha & 6753 \\
\hline $\mathbf{5}$ & Koteshwar & Danta & Banaskantha & 1126 \\
\hline $\mathbf{2}$ & Chikhla & Danta & Banaskantha & 1172 \\
\hline $\mathbf{1}$ & Baga & Danta & Banaskantha & $1000-1500^{*}$ \\
\hline $\mathbf{6}$ & Hadad & Danta & Banaskantha & 3144 \\
\hline $\mathbf{3}$ & Kheroj & Khedbrahma & Sabarkantha & 1014 \\
\hline $\mathbf{3}$ & Jetalpur & Mehsana & Mehsana & 1331 \\
\hline
\end{tabular}

Table 1: List of villages covered in the study

\section{Analysis}

The transcripts were subjected to grounded theory based analysis (Glaser and Strauss, 1967). Three independent investigators read the transcripts. They conducted open coding these transcripts which generated 533 general descriptions of brand selection criteria employed by the retailers. The emerging codes were also searched through previous literature on the subject in order to identify whether the codes could be related with any theme from the relevant literature. Thereafter a round of axial coding (Strauss and Corbin, 1998) was conducted to sort the descriptions into 99 sub-themes. The available 99 were further analysed to create 15 concepts that described the major themes as emerging from the interviews. The details of the emerged sub-themes, concepts and the categories have been shared in Annexure A. These concepts were then further classified into 4 categories that served as the major constructs of the BoP retailers' brand adoption criteria.

\section{Findings}

\section{BRAND RELATED FACTORS}




\section{Brand awareness}

"The brands which are advertised on TV or newspaper generally sell more than the non-advertised brands. When a vendor comes and shows his new brands and I reckon having seen it on TV, I will keep it in my shop."

Stocking well-known and established brands was universal. All retailers would stock these brands as customers would ask for such brands and would leave without purchasing if the desired brand was not available. These retailers considered advertised brands as established brands and were only interested in stocking them. These retailers stocked only known brands because they believed that advertised brands had better product quality as compared to non-advertised brands and for these retailers product quality was an important driver of sales. They did not differentiate between national or local or MNC brands.

However, it was observed that all retailers also stocked lesser known brands in the same product category. One of the primary reasons of retailers in stocking lesser known brands was that these brands offered higher sales margins than known brands. The known brands sold in larger quantities but offered lesser margins. Therefore, by stocking both known and other brands retailers increased their overall profit as also served to a wider segment of customers. The other motivation to select lesser known brands was that these brands were available on credit, unlike the established brands.

"Yes, I will keep it. There are many national political parties but that doesn't mean regional parties will not emerge. So many major and reputed brands like $<$ Brand $A>$ have entered the market but that doesn't mean that you will not sell anything other than $<$ Brand $A>$. Nobody can do business like this. If I have to do business I cannot keep on speculating whether this will sell or the other."

Many retailers shared that when they come across a brand which they were not aware but it enjoyed clear demand in some other market, they would be very interested in stocking that brand. At the same time, few retailers also mentioned that they would not be willing to stock the products of a brand, whose name they have never heard before. Thus, highlighting 
that minimal brand awareness was an important pre-requisite before finalizing the brand. Very few retailers were reluctant to stock brands whose names they have never heard of.

\section{Brand promotions}

"Once a company gave me an offer that when I purchased 5-6 boxes of its product, they will give me 2 more free boxes. But at that time I said that I don't want any type of offer or any extra boxes. If your product sells then you will get the money, If it doesn't..."

At the distribution level, retailers and other channel partners are often given extra stock on the purchase of a minimum quantity. This would essentially increase the retailer's profit margin and turnover. However, the BoP retailers were divided in their opinion.

"I want to look for profits but these companies play tricks. Earlier this 100 gram packet of biscuit was sold at $R$ s 5 . In recent times the brand reduced the quantity to 60 grams and now they have decreased the quantity further. But the price remains the same. So I can't earn enough margins"

About half of the retailers interviewed were not particularly motivated to select a brand just because they have a launch scheme or discount to offer. Although the promotional offers influenced the retailer's purchase decision but it did not do so as a standalone factor. For these set of retailers, other aspects of selection process, for instance, customer demand, were more important than discounts. Retailers were interested in adopting a brand if it was sold and not because the brand or supplier was offering free boxes with a purchase. Their primary apprehension was that under the pretext of discounts and freebies brands would dump their stock at their shops and in case if that stock is not sold then they will have to suffer huge losses. Such a scenario would completely reverse the underlying objective with which the retailers had purchased the stock. Other forms of brand promotions, such as television advertisement, newspapers advertisement and others, did not motivate all of them to adopt brands. The retailers' reasoning was that such forms of marketing work only in urban centres where the customers are educated and that in their rural areas such promotions did not help them increase sales. This brings out an important point that the 
retailers considered brand promotion as a determinant in selecting brands only when brand promotions were effective in reaching the consumers and in increasing sales.

"Mostly for any new brand they give 30-40\% margin otherwise they give free packet, meaning if I buy defined stock quantity I get 5 packets free and other such schemes. Established brands do not offer that much profit. Take the example of $\langle$ Brand $X>$ which does not give me any discounts but $<$ Brand $Y>$ gives me 5 packets extra. I earn the similar margins through both the brands. But I got extra 5 packets in $\langle$ Brand $Y>$ and thus I will get more profit in $\langle$ Brand $Y\rangle$. So, whenever a customer demands biscuits of Rs.5, I give them <Brand $Y>$. But I also have to keep $<$ Brand $X>$ as many customers demand it with its name. We retailers do business only when we get at least Rs.110 in return for giving Rs100."

About half of the retailers have also shared that brand promotions influenced their decision making process and the reason understood is two-fold. Firstly, promotions involving discounts and schemes were welcomed by a lot of retailers as they help the retailer to increase his/her overall profit margin. Since the turnover of BoP retailers has been found to be less compared to their urban counterparts, BoP retailers have shown an inclination to adopt brands that help them increase overall profit margins. For example, providing retailers free units of a product on purchase of a minimum quantity will increase the average margin per unit of the total purchase. And secondly, promotional schemes for customers, such as buy-one-get-one-free, also positively influence the retailers' decision as they feel that such offers will motivate customers to buy the product and thus increase the retailers' sales.

\section{Brand reputation}

"If a new product is launched by a reputed brand I am willing to take risk of selling it because when a reputed brand launches a product then I think the product is also good." 
Most of the retailers showed their interest in adopting brands that enjoyed a good reputation. The assessment of reputation was based on the perceptions of the channel members, other retailers and consumers. In addition, the retailers also mentioned that they considered other parameters such as consistent product quality, good product packaging and price. So, if the quality of a previous product launched by a brand was considered good then the quality of subsequent products launched by the same brand was also considered to be good and vice versa.

A lot of retailers did not understand the concept of umbrella brands. As a result, none of these retailers had any inclination in stocking a brand based on the name of the company, even when they were selling other brands from the same corporations. Those who recognized the umbrella brand only displayed an inclination not the decision to adopt the brand. Retailers were apprehensive of selling just any brand from even a known company when the demand was uncertain.

" $<$ Brand $M>$ is a good company but it will have to first experiment its new product in the market. This is also needed because they should be conscious that their name should not be ruined in other products too. So the quality of the product is major factor".

A small number of retailers shared that brand reputation did not influence their decision making process. For these retailers other aspects were more important. For instance, retailers shared that the product quality is important than the brand value. In cases where a brand is launching a new category brand or a new product, these few retailers were willing to stock the brand only if the product quality was good as per their standards. This emphasized on how few retailers were considered product quality more important than brand value and how most other retailers considered product quality only as a mechanism to assess brand value. A small number of retailers also indicated that the customer demand was a more important criterion than brand value and that if customers demanded a brand then the retailers would stock it irrespective of the brand's reputation. They also added that when some of their customers asked for a product than a specific brand, the customers simply bought the product possibly because the brand did not exist for them. 


\section{Demand}

"In our business, we have to know what customers will buy. If the customers want only one of those two brands, then we will only purchase that brand and if the customers like both of them, then we will purchase both of them."

The most significant factor defining brand adoption process of the BoP retailers was demand for the brand. Almost all retailers have stated that the demand of a brand guided their purchase behaviour. Higher the demand of a brand, higher was the chance that the retailer will adopt the brand and vice versa. In fact, if a brand did not have any distinct demand in the market then the chances of rejection by the retailers are very high even if the brand offered higher profit margins, promotional offers and attractive packaging. A lot of retailers were reluctant to take any risks and emphasised that the demand of the brand was more important than any other factor. Other factors were considered in the decision making process after assessing the demand.

BoP retailers assessed demand from customers and from the market. The validation of demand through sources in the market like the wholesaler and other trade partners was a common practice in the case of recently launched brands. The other method involved understanding the needs of the customers. Most retailers gave priority to their customers. If a brand did not have a distinct demand among the consumers then it was clearly rejected by the retailer. In some cases retailers relied on their own judgement of what were the requirements of the consumers and then decided on the whether to stock the brand.

"We try to know what products and brands that are primarily consumed in the village, what the people of the village want, etc. Then we order as per that understanding. We order the products and brands that are regularly sold"

Most of the retailers mentioned distinctly that there existed no competition among the retailers of a village. Most of these retailers generally served different areas and unless goods were not available with one retailer, the customer would not commonly go to another retailer. 
"No there is nothing like that. We decide what we want to keep and he decides he wants to keep. So there is nothing like that because if he is selling a brand then I should also sell that brand"

Majority of the retailers were not inclined to stock a brand just because another retailer from the village also stocked the same brand. That being said, retailers did share that when any retailer added a new brand to their portfolio, the other retailers of the village would observe the sales of that brand for a certain period. If the brand sold well in the village then the others retailers would he would be highly motivated to stock the same brand. But if the brand did not sell any units in the village then the brand would not be stocked by any retailer in and sometimes around the village. Retailers often assessed the demand of the newly added brand from customers. For instance, if customers demanded a particular brand, which was available at another store, then the retailer would be inclined to stock that brand.

Price

"No I wouldn't sell a brand just because it is reputed I also need to consider the price. For example, we don't sell $<$ Brand $Q>$ belonging to the corporate $<$ Brand $R>$ even when we sell a lot other brands from $<$ Brand $Q>$. This is because $<$ Brand $R>$ particularly is very expensive"

Income of the customers played an important role in the buying patterns of the retailer. Majority of the retailers were averse to stocking expensive brands. This was primarily driven by the concept that BoP population, with their low incomes, wouldn't be able to afford expensive products irrespective of the brand of the product. Moreover, new brands that were very expensive, as compared to the regular brand in the same product category, would also face rejection by the retailers. The reasoning was that if a brand is already achieving good sales in a category then new introductions, with higher pricing, are not accepted well in the market, forcing the retailer to reject the expensive brand. However, exceptions to this rule were also noted. 
"See there are brands like $<$ Brand $K>$ and then there are brands like $<$ Brand J $>$. $<$ Brand $K>$ products are slightly expensive but then again they achieve good sales in this village because the quality of products of $<$ Brand $K>$ is better than other brands. So even if the price is slightly higher still we sell $<$ Brand $K\rangle^{\prime \prime}$

In cases where the difference in price, between two competing brands, was found to be little, then retailers preferred the expensive brand, provided the product quality of the expensive brands was distinctly better than the cheaper brand and this had to be validated by the customers. Such a practice goes further in elucidating that price is a defining criterion but definitely not a limiting one and that quality still was appreciated in the BoP segment.

\section{BUSINESS DEAL RELATED FACTORS}

\section{Influence of sales margin}

"If a new brand gives me higher sales margin, as compared to the regular brand, then I will be inclined to stock that brand because that brand will increase my profit."

Earning profit is central to doing business and for the BoP retailers it was no different. The fixed expenses of the retailers were minimal. In most cases, they owned the shop. Only a few large ones had more than 1 worker. In many cases they were from the family. They couldn't be reduced any further. Also they did not deal in large volumes. Therefore, the only way to earn greater profits was by increasing the effective sales margin that they received on selling the stock. But it was also important to note that the retailers were not enthusiastic to adopt any brand just because they were offered higher margins. The retailers further shared that the brand should also have higher sales, as judged by the weekly or monthly sales figures of that brand. Such a practice is justified as higher profits margins would be of no use if the sales figures are not good enough. Therefore, such a selection process defines the BoP retailer's idea of greater business emerges not only from margins but also from sales. 
"No, I can't prompt my customers just for the sake of more profit. I also have to look at the quality of the product. If I prompt my customers to buy a not-so-good brand just because it gives me more profit than the standard one, and if the customers have a bad experience with that brand then they can lose faith in me. Next time they will not come to me"

The above account throws light on the fact that a BoP retailer's decision to stock brands that offer higher margins in not only based on higher sales figures but also on the customer experiences. These retailers had expressed their concern over adopting brands solely on the basis of higher margins because a bad customer experience, with the brand, will make the retailers lose their customers, eventually ruining the retailers' sales.

\section{Influence of credit facility}

"Yes I would be interested to buy if credit facility is available. So I tell my distributors that if you want to sell me a brand then give it to me on credit. I don't have money. From whatever I sell I will pay you. If it doesn't sell, then you would have to take back the stock."

Most of the retailers have stated unambiguously that they would be open to adopt a product provided they do not have to pay the wholesaler any amount upfront. They would not like to invest a new brand upfront. The retailers would pay the amount for the units sold as they sell. The wholesaler should be ready to take back all the stock, even if a single unit of the stock did not sell. Some of the retailers had also emphasised on the presence of good product quality and sufficient promotions over the practice of credit facility. Although very small in number, there were some retailers who would not adopt brands even when the wholesaler or the distributor provided credit facility.

\section{Buy-back facility}

"If my wholesaler or distributor is willing to buy back all unsold stock then I can plan to stock a brand they recommend" 
One of the other emerging factors that influenced the retailer's decision making process was the offer of a buy-back facility by the wholesaler or the distributor. Such a facility helped retailers sell back all unsold stock to their respective wholesaler or distributor. Such a provision further validated that retailers were interested in stocking more brands and products but not at the cost of piling up unsold stock. Another important variation understood in this working method was that retailers would only enter into such a provision with a known wholesaler or distributor. This was because retailers would not easily trust a new wholesaler or distributor who may offer this facility but then never come back again to buy back the unsold stock. Very few retailers were not willing to stock a brand that came with a buy-back facility.

\section{Replacement and return facility}

"I keep new brands only if distributor offers replacement. Otherwise he will definitely say that "this brand is good" but what if it doesn't get sold? I don't take such risks. If distributor is ready to take the risk and gives me replacement offer, then I'll keep the new brand."

A large number of retailers were also willing to stock a brand provided the vendor (the distributor or the wholesaler) was ready to replace unsold stock of the brand with the stock of any regularly purchased brand. Retailers were trying to minimize their risk which may arise out of any unsold stock and at the same time they were trying to explore and add a new rage of merchandise that could enhance their earnings. It suited the wholesalers also as they would prefer to sell the stock instead of giving it on credit. Also they would take back the unsold stock instead of returning the money which helped experimentation without affecting their turnover. This apparently created a win-win situation both for the wholesaler and the retailer.

Some of the retailers were ready to indulge in such a practice only if the vendor was known to them or in any manner by which the vendor could be trusted. This hesitation was based on their past experiences where new vendors would sell them on the pretext that they will exchange the unsold stock with the stock of a brand of the retailer's choice. But the once 
the goods were accepted by the retailers these vendors never returned and the unsold stock added to the loss of these retailers.

"In case the goods are not sold then we give it back to the distributor. You see these biscuits, this brand is selling but this brand is not selling and so I am going to give it back to him."

Some retailers sought buy-back facility where the vendors would return the money in the case of unsold goods. This condition was applicable when the retailer paid for the stock upfront as against buying it on credit. Under such a circumstance the retailers would hand over the unsold stock to the wholesaler and get his money back.

\section{Initial investment}

"Initial risk will depend on my capacity. For me, say 2 dozen units or about Rs 200-250 is the maximum initial investment that I can take. I can't take more risk. What in case the brand doesn't sell? And if it sells then I can buy more next time"

Though very few in number but retailers mentioned that they were willing to adopt brands only if the initial investment was very small. Such a strategy was used to set-off the initial risk that may arise by selecting non-performing brands. Moreover, because it is difficult to accurately ascertain the sales potential of a brand or a product low initial investment could be a healthy way for the retailers to make an estimate of the sales potential and then finally decide on the modus operandi for future purchases. It was further interesting to note the variation in the amount of initial investment BoP retailers were willing to make. For some the range was from Rs 200 to 250 and for some it was from Rs 1000 to 2000 . So although the underlying logic was similar but the initial risk capacity was different for different BoP retailers.

\section{RELATIONSHIP RELATED FACTORS}




\section{Influence of the wholesaler}

The retailers bought most of their merchandise from the wholesaler from the nearest 'taluka'. A small proportion of merchandise was also delivered to the retailers in most villages by company appointed distributors.

"If the wholesaler insists then we have to stock the brand. My vendor once came with $\langle$ Brand $C\rangle$, which I stocked but it didn't sell much. The products were third class. He then asked me to stock $\langle$ Brand $D>$. He is an old vendor of mine and someone who can give stock worth Rs 25,000 on credit, so I stocked <Brand D> as well"

The wholesaler played an important role in the brand adoption process of the retailers. Nearly all of the retailers shared that they were willing to buy brands, which the wholesaler encouraged the retailers to stock. Wholesalers would often suggest and insist retailers to buy specific brands and the retailers would comply. Moreover, the length of the relationship with the wholesaler or the distributor also plays a key role. Retailers have explained their disinterest in stocking brands suggested by new or unfamiliar vendors and they found it difficult to trust these new vendors. The retailers also shared that their hesitation in trusting new vendors emerged from previous setbacks, which they encountered after believing in the claims of these new vendors.

Many retailers, who stocked brands as per the wholesaler's recommendations, did so under the condition that if the goods were not sold then the wholesaler would take them back.

"I am willing to sell the brand from the wholesaler subject to the conditions with the company that, "I'll keep it at my regular retailers" shops. But if it is not sold, you will have to take it back. My name should not be ruined in other brands." This condition would also apply to him. Now, I have regular business with him. So, he also knows my conditions."

Retailers were averse to taking risks and are not prepared to ruin their relationship with their customers. Even when a wholesaler would suggest the retailer to stock a brand, the retailer is only willing to do so when the wholesaler is ready to take back the unsold stock. And such a condition is pre-set by the retailers with their wholesalers. Further investigation 
about the role of wholesaler and distributor in the brand selection process revealed how some retailers gave preference the vendors from their own caste.

"Yes I give importance to people of my caste. I have feelings for my caste. Then if the other person, of my caste, does not have such feelings and he is not interested, then that would be a separate case. But I would give him the first preference. If I buy goods from him, then he would earn a bit."

About half of the BoP retailers interviewed have shown an inclination to buy goods from the wholesaler of their caste. They would like to give the first preference to wholesaler from their caste as these retailers want the people from their caste to prosper. However, they may not select all brands that these wholesalers deal in. They would also expect the wholesaler to reciprocate.

"Even if my real brother tells me to put a brand in my shop, I would still enquire first. So first I look at the brand and not at the caste."

The other half of the retailers stated that they would not let caste and creed influence their business decisions. These retailers have gone further to share that aspects such as product quality and profit margin are important to them than the wholesaler's ethnicity. These retailers were willing to switch from a wholesaler of their caste if another wholesaler from other caste was giving higher profit margin.

\section{Influence of relationship with customers}

"What if the brand doesn't sell in the market? In such a case even if they offer higher margins but that doesn't make sense... Even if they give it for free and if the customer becomes unhappy then the brand will ruin my name. I hope you understand that I can't afford to do anything like that"

Some of the retailers were not even willing to accept any brand that did not have a predefined demand in the market or among its buyers. According to them by adopting and then pushing unwanted brands to its customers retailers tend to ruin their relationship with their customers. Such a scenario may lead to two possible outcomes. Firstly, a dissatisfied 
customer will not return to buy from the retailer and thus ruin his future business. And secondly, considering that BoP retailers live in a very small and closely knit society of the village, maintaining a healthy and positive relationship with others residents becomes an important priority.

\section{Influence of family}

"My brother and I jointly manage the shop. So whoever is present at the shop will decide what to purchase"

All the retailers who were interviewed were males and a lot of them managed the shop along with their male sibling. Therefore, the final decision about brand purchase is not necessarily taken by one and only one person rather the process may even incorporate suggestion from all brothers. In the presence of the father, retailers have also gone ahead to share that their father takes the final decision. Another retailer states that he might have to undertake the suggestions from his wife. Therefore, some of the retailers base their brand purchase decision as per the recommendations of the mature members in the family.

\section{PRODUCT RELATED FACTORS}

\section{Product Quality}

"Quality is the first thing. If the quality is good then I am ready to keep it otherwise not. You see if the quality is good then only a product gets sold and then only I will be able to earn 2 paisa as profit. I wouldn't stock it otherwise."

Product quality found universal appeal as a defining brand selection criterion. A large number of retailers were found to consider product quality of a brand's stock as one of first brand selection criterion. The BoP retailers' believed that better product quality would increase the probability of achieving higher sales and vice versa. Retailers also revealed that it was in their benefit to supply good quality products to their customer with whom their relationship could be ruined otherwise. They considered a good quality product core to their relationship with the customers. 
Quality was assessed in many ways. Some retailers considered the brand reputation as a measure of quality. Others considered the product packaging and product quality as different aspects, wherein the content of the product (quality) was more important than the packaging. A lot of retailers considered the product's taste and purity, especially in case of edible products, to be the measure of the product's quality. These retailers would taste the product themselves or ask a customer to try the product and then decide on stocking the brand. Some retailers also thought that price was connected with the quality. They would often assume that low priced brands did not offer good quality and would refrain from stocking them.

\section{Influence of packaging}

"Consider these two brands; both of them are similar in taste. The packing of $\langle$ Brand $U\rangle$ is more attractive than $\langle$ Brand $V\rangle$. The colour is also bright. <Brand $V>$ has a dull coloured packaging. Nowadays packaging has to be multi-coloured. Now here is $\langle$ Brand $W\rangle$. There is nothing in it. But due to its multi-coloured and attractive packing, children want to have it."

Most retailers indicated that packaging of a product played an important role in helping them select the brand. They wanted the package to be attractive which motivated customers to buy, thus increasing their sales. Retailers were of the opinion that attractive packaging helped in trials and after purchase it was the product performance and taste in case of the edible products that helped them to determine the sales potential. They feel that unlike the urban consumers, the village population is easily attracted by eye-catching packaging designs. According to the BoP retailers an attractive design would involve a vibrant use of colours and relevant imagery, for example using the image of a girl in soap brand. In addition, most retailers would ask for good attractive packages, especially for products targeted at children as they felt children were gullible to buying products with an attractive packet design. Another aspect of design that was elucidated in the interviews was the clear mention of expiry date and maximum retail price on the packet. This was important as it gave BoP retailers the confidence that neither are they or their customers 
being asked to pay more than the maximum retail price nor are they being handed expired or near expiry stock, thus ensuring good product quality.

"In villages, the criteria are very simple. First of all people gets attracted towards attractive packing, then comes the quality and quantity. The quantity of the product should be greater than the competitor's brand. Also when the customers try it for the first time, they should be satisfied with the product"

Few retailers also stressed on the necessity to have a greater quantity of the product than the regular or the competitor brand in the same product category. Many have wanted bigger pack size which was also likely to attract customers, who would tend to buy that brand under the pretext that it contains a larger quantity of product as compared to the regular brand in the same category. However, the price of the product should remain unchanged. BoP retailers were uncomfortable in adopting brands with a price point higher than the regular price for the specific stock keeping unit (SKU).

"For products like potato chips, the price of a brand can only be plus minus 25-50 paise. In fact the price should be the same. For instance, if the routine brand sells a 100 gram-packet at Rs 10 then the new brand cannot be sold at Rs 11"

Another aspect of packaging that was being considered was the packet weight/volume unit. Retailers displayed their willingness to select brands that were available in smaller unit packaging. One reason behind the preference of smaller SKUs was that customers could buy according to their usage and frequency of use. Also because customers could not afford higher price for bigger SKUs retailers, too, preferred purchasing smaller SKUs.

\section{Discussion}

The factors considered by retailers in adopting a brand could be classified as brand related, business deal related, relationships related and product related. The diagram in figure -1 illustrates the relationship among them: 


\section{Figure - 1: A Theoretical Framework for Brand Adoption by BoP Retailers}

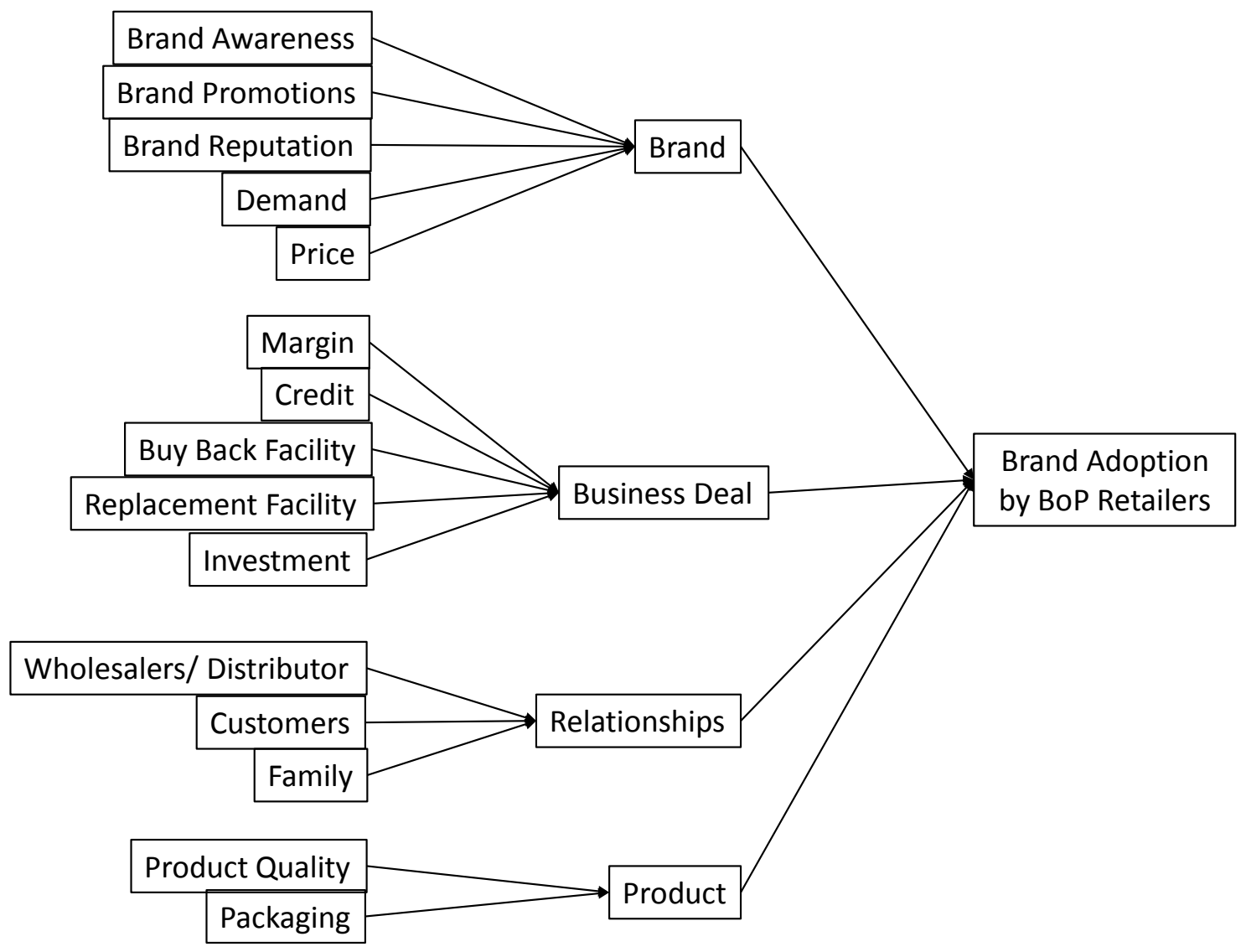

Retailers selling to BoP markets need to manage a different shopping behaviour as compared to other segments. The customers buy frequently and in small quantities. They would hardly stock much. Barring a few products where the consumption life is longer such as soaps or the pack size is large like salt, they would be buying them twice a week. Products like snacks and shampoos would be bought as and when needed. Consequently, these stores do not stock large quantities of any merchandise. Also their shops are small as they start the business with very low capital investment. Retailing is practiced as a working capital based business. The risk in business is also reduced by stocking brands that are in demand or where the wholesaler assured returns. This importance of consumer demand follows the previous findings by Grashof (1970). The inventory held by BoP retailers is small and the demand based decision ensures higher churns leading to better ROI (Return on Investment) over the year. They prefer to stock brands with definite demand than those with higher profit margin. However, they tend to mix these two classes of brands to build 
variety as well as enhance profitability. This is synchronous with the research Dholakia et. al, (2012), which stated that because of limited space, small retailers aim for a continuous and a quick stock turnover.

Another interesting point to note and compare with previous literature is that brand promotions certainly influenced the retailers' decision especially but not in the form of advertising, which was specified by Heeler et. al. (1973), Montgomery (1975) and White et. al. (2000). This is not completely surprising as the previous research has largely included empirical data from urban and organized retailers, whereas the dynamics of the BoP markets is expected to be different. At the same time the findings related to the effect of brand promotions, especially in the form of channel level promotions, offers and discount schemes, is largely synchronous with previous research done by Aliwadai (2001) and White et. al., (2000). The present research findings pertaining to the importance of brand reputation has also followed with earlier studies by Montgomery (1975) and White et. al. (2000).

Moreover, in elucidating 18 variables that define the a retailer's acceptance or rejection criterion for new products, Montgomery's (1975) research overlaps with the present study in aspects of brand reputation, quality, packaging and margins. Similar overlap was observed with the research done by White et. al. (2000) with respect to aspects of estimated profit, gross margin and manufacturer reputation. Importance of credit period (Dholakia et. al, 2012) has been further highlighted in the present study and retailers have further gone and shared their inclination in adoption of brands that provide replacement and buy-back facilities.

BoP retailers' relationship with their customers is paramount. They would give what the customers want and refrain from unknown products which may endanger the relationships. Since they serve a small market and are part of the community, the business transactions are shaped by their social relations. This relationship is used to assess demand for new products. Customer feedback is the final word for them. The late emergence of the study of the impact of relationship on the purchase process (Kaufman, 2006) is further validated in this study where the relationship with wholesaler/distributor, customers and family members forms a very defining part of the decision. The existence of close ties among 
ethnic communities (Dholakia et. al., 2012 and Varman et.al., 2009) in retail has been corroborated in this research, which highlights how some retailers have given preferences to the recommendation of the wholesalers and distributors belonging to their caste. Furthermore, the BoP retailers shared their ease in complying with the recommendations of wholesalers whom they have known for a longer period of time, taking ahead the findings of Jap and Anderson (2007) about the importance of length of relationship.

\section{References:}

Ailawadi, Kusum L. (2001), "The Retail Power-Performance Conundrum: What Have We Learned?," Journal of Retailing, 77, 299-318

Bronnenberg, Bart J. and Carl F. Mela (2004), "Market Roll-Out and Retailer Adoption for New Brands," Marketing Science, 23 (4), 500-18

Burgess S. and Steenkamp J.E.M. (2006), "Marketing renaissance: How research in emerging markets advances marketing science and practice", International Journal of Research in Marketing, 23(4): 337-356

Corsten, Daniel and Nirmalya Kumar (2005), "Do Suppliers Benefit from Collaborative Relationships with Large Retailers? An Empirical Investigation of Efficient Consumer Response Adoption," Journal of Marketing, 69 (July), 80-94

Dabas C.S., Sternquist B. And Mahi H. (2012), "Organised retailing in India: Upstream channel structure and management", Journal of Business and Industrial Marketing, 27(3): 176-195

Dholakaia N., Dholakia R.R., and Chattopadhyay A., (2012), "India's Emerging Retail Systems: Coexistence of Tradition and Modernity", Journal of Macromarketing, 32(3): 252-265

Glaser, B. G. Strauss, A. L. (1967), “The Discovery of Grounded Theory”, Chicago: Aldine

Grashof, John F. (1970), "Supermarket Chain Product Mix Decisions Criteria: A Simulation Experiment," Journal of Marketing Research, 7 (2), 235-42

Heeler, Roger M., Michael J.Kearney and Bruce J. Mehaffey (1973), "Modeling Supermarket Product Selection," Journal of Marketing Research, 10 (1), 34-7

Jap, Sandy D. and Erin Anderson (2005), "The Dark Side of Close Relationships," MIT Sloan Management Review, 46 (3), 74-82

Kaufman, Peter, SatishJayachandran and Randall L. Rose (2006), "The Role of Relational Embeddedness in Retail Buyers' Selection of New Products," Journal of Marketing Research, 43 (November), 580-7 
Kumar, Nirmalya, Lisa K. Scheer and Jan-Benedict E.M. Steenkamp (1995), "The Effects of Perceived Interdependence on Dealer Attitudes," Journal of Marketing Research, 32 (3), 348-56

Kumar, Nirmalya and Jan-Benedict E.M. Steenkamp (2007), Private Label Strategy: How to Meet the Store Brand Challenge, Boston: Harvard Business School Press

Lariviere, Martin A. and V. Padmanabhan (1997), "Slotting Allowances and New Product Introductions," Marketing Science, 16 (2), 112-28

Montgomery, David B. (1975), "New Product Distribution: An Analysis of Supermarket Buyer Decisions," Journal of Marketing Research, 12 (3), 255-64

Prahlad (2004), "Fortuneat the bottom of the pyramid: Eradicating poverty through profits", Pearson Prentice Hall, USA.ISBN-10: 0-13-146750-6.

Rao, Akshay R. and HumairaMahi (2003), "The Price of Launching a New Product: Empirical evidence on Factors Affecting the Relative Magnitude of Slotting Allowances," Marketing Science, 22 (2), 24668.

Rao, Vithala R. and Edward W. McLaughlin (1989), "Modeling the Decision to Add New Products by Channel Intermediaries," Journal of Marketing, 53 (January), 80-8

Reinartz, W., Dellaert B., Kraff M., Kumar V. And Varadrajan R. (2011), "Retailing innovations in a globalizing retail market innovation", Journal of Retailing, 87(1): S53-S66.

Strauss, A. Corbin, J. (1998), "Basics of Qualitative Research: Techniques and Procedures for Developing Grounded Theory", Thousand Oaks, CA: Sage.

Varman R. and Costa J. A., (2009), "Competitive and Cooperative Behavior in Embedded Markets: Developing an Institutional Perspective on Bazaars", Journal of Retailing, 85(4): 453-467.

White, J. Chris, Lisa C. Troy and R. Nicholas Gerlich (2000), "The Role of Slotting Fees and Introductory Allowances in Retail Buyers' New-Product Acceptance Decisions," Journal of the Academy of Marketing Science, 28 (2), 291-298. 


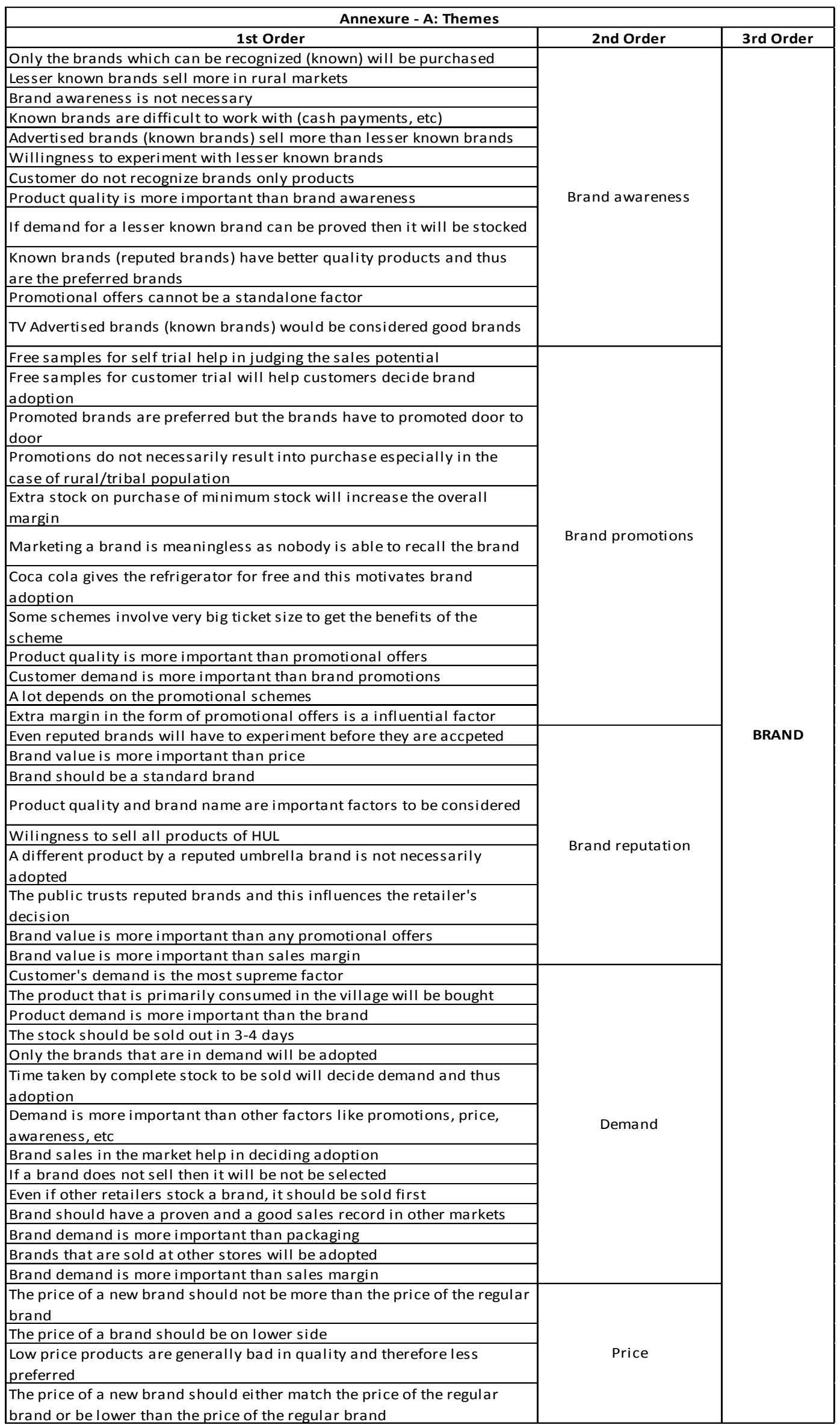




\begin{tabular}{|c|c|c|}
\hline \multicolumn{3}{|l|}{ Annexure - A: Themes } \\
\hline 1st Order & 2nd Order & 3rd Order \\
\hline $\begin{array}{l}\text { Overall business profit should be at least big enough to accomodate } \\
\text { retailer's daily expenses }\end{array}$ & \multirow{6}{*}{ Profitability } & \multirow{19}{*}{ DEAL } \\
\hline If there is no profit then the brand will be rejected & & \\
\hline $\begin{array}{l}\text { If margin is high then even new brands will be adopted. Retailers then } \\
\text { push these high margin brands }\end{array}$ & & \\
\hline $\begin{array}{l}\text { Even if sales margin is higher than the regular brand but a new brand } \\
\text { may not be adopted }\end{array}$ & & \\
\hline Lesser known brands give more margins & & \\
\hline Profitability is an important criterion & & \\
\hline $\begin{array}{l}\text { Merchandise should be available on credit such that payment will only } \\
\text { be done after goods are sold }\end{array}$ & \multirow{4}{*}{ Credit facility } & \\
\hline $\begin{array}{l}\text { When a distributor introduces a brand then he can keep can keep the } \\
\text { stock in the retailer's shop but only on credit }\end{array}$ & & \\
\hline New brands will be stocked on credit & & \\
\hline Even known new brands have to be initially stocked on credit basis & & \\
\hline Brands offering buy-back facility are preferred brands & \multirow[b]{2}{*}{ Buy-back facility } & \\
\hline $\begin{array}{l}\text { Brands offering buy-back facility are preferred brands only if the } \\
\text { supplier is a known person }\end{array}$ & & \\
\hline Brands offering replacement facility are preferred brands & \multirow{4}{*}{ Replacement facility } & \\
\hline $\begin{array}{l}\text { Retailers are not ready to take the risk of unsold stock. This stock should } \\
\text { be replaced }\end{array}$ & & \\
\hline Replacement has to be done with a regular brand & & \\
\hline The brand should be sold out in 1-2 weeks else it has to be replaced & & \\
\hline Initial investment has to be low & \multirow{3}{*}{ Initial investment } & \\
\hline $\begin{array}{l}\text { A risk of Rs 300-500 is doable depending upon the product but not } \\
\text { beyond that }\end{array}$ & & \\
\hline Initially a very small quantity of stock can be purchased & & \\
\hline $\begin{array}{l}\text { Brands will be adopted on the wholesaler's insistence because of the } \\
\text { relationship }\end{array}$ & \multirow{12}{*}{ Wholesaler/Distributor } & \multirow{17}{*}{$\begin{array}{l}\text { RELATIONSHIP } \\
\text { QUALITY }\end{array}$} \\
\hline $\begin{array}{l}\text { Brands may not necessarily be adopted just on the wholesaler's } \\
\text { insistence }\end{array}$ & & \\
\hline Wholesaler should be ready to take back unsold stock & & \\
\hline Brand/product saleability is as important as the wholesaler's influence & & \\
\hline Brand demand is more important than wholesaler's influence & & \\
\hline Wholesaler's influence matters when he is giving offers on purchase & & \\
\hline $\begin{array}{l}\text { Because of regular and high volume business with a wholesaler, the } \\
\text { retailer would comply with the the wholesaler's suggestion }\end{array}$ & & \\
\hline The quality of the relationship with the wholesaler should be positive & & \\
\hline $\begin{array}{l}\text { Old wholesalers are more influential than new wholesaler as new } \\
\text { wholesalers may not return }\end{array}$ & & \\
\hline $\begin{array}{l}\text { Retailers do not consider wholesaler's caste as an influential factor. } \\
\text { Demand and quality are more important }\end{array}$ & & \\
\hline $\begin{array}{l}\text { Retailers have a tendency to give importance to wholesalers from their } \\
\text { caste }\end{array}$ & & \\
\hline $\begin{array}{l}\text { Retailers work with wholesalers who give the retailers maximum } \\
\text { possible margin, irrespective of the caste }\end{array}$ & & \\
\hline $\begin{array}{l}\text { Quality is more important than margin because a bad quality product } \\
\text { can ruin relationship with customer }\end{array}$ & \multirow[t]{2}{*}{ Customers } & \\
\hline All brands requested by customers will be kept & & \\
\hline $\begin{array}{l}\text { In case the shop is managed by } 2 \text { brothers then generally both can take } \\
\text { decision }\end{array}$ & \multirow{3}{*}{ Family } & \\
\hline Retailer may take suggestions from family members & & \\
\hline $\begin{array}{l}\text { Even if a family member insists to buy a brand still the brand's other } \\
\text { aspects have to considered before purchase }\end{array}$ & & \\
\hline
\end{tabular}




\begin{tabular}{|c|c|c|}
\hline \multicolumn{3}{|l|}{ Annexure - A: Themes } \\
\hline 1st Order & 2nd Order & 3rd Order \\
\hline $\begin{array}{l}\text { Packaging has to be attractive as children often purchase on packet } \\
\text { visuals }\end{array}$ & \multirow{6}{*}{ Packaging } & \multirow{12}{*}{ PRODUCT } \\
\hline People in villages tend to buy attractive packaging & & \\
\hline $\begin{array}{l}\text { Because the customers are price sensitive they prefer to purchase small } \\
\text { packets against bigger packets }\end{array}$ & & \\
\hline $\begin{array}{l}\text { Packaging visual should be related with the product, like the photo of a } \\
\text { girl on a soap packet }\end{array}$ & & \\
\hline $\begin{array}{l}\text { Packets bigger than the packets of the regular brand are expected to give } \\
\text { more sales }\end{array}$ & & \\
\hline $\begin{array}{l}\text { Packet should clearly mention important details, such as expeiry date, } \\
\text { MRP, weight, etc }\end{array}$ & & \\
\hline Product quality is more important than packaging & \multirow{6}{*}{ Product quality } & \\
\hline Product quality is a very important factor. Quality should be good & & \\
\hline $\begin{array}{l}\text { In case of edible products, taste and aduletration level are important } \\
\text { quality parameters }\end{array}$ & & \\
\hline Quality matters first & & \\
\hline Low price products may have a bad quality and may not be adopted & & \\
\hline Good product quality ensures repeat purchase by customers & & \\
\hline
\end{tabular}

